DOI: $10.17951 /$ lrp.2019.38.1.177-189

\author{
Anna Kalarus \\ Akademia Muzyczna w Krakowie \\ ORCID: 0000-0001-7759-006X
}

Gabriela Karin KonKol

ORCID: 0000-0002-5007-7669

Akademia Muzyczna im. Stanisława Moniuszki w Gdańsku

\title{
MIEJSCE KREATYWNOŚCI W KRAKOWSKIEJ KONCEPCJI WYCHOWANIA MUZYCZNEGO
}

\begin{abstract}
Streszczenie: W artykule zostanie przedstawiony dorobek krakowskich naukowców zaangażowanych w poszukiwanie skutecznych metod nauczania muzyki w szkolnictwie ogólnokształcącym. Ośrodek krakowski powstał z inicjatywy Zofii Burowskiej w połowie lat 70. XX wieku. Członkami zespołu zostali pracownicy akademiccy ówczesnej Wyższej Szkoły Muzycznej i Wyższej Szkoły Pedagogicznej. Przyjęto założenia programowo-metodyczne, których podstawą jest metoda solmizacji relacyjnej, wywodząca się z angielskiej metody Tonic-Solfa Johna Curwena oraz koncepcji Zoltána Kodálya. Istotną rolę w Krakowskiej Koncepcji Wychowania Muzycznego pełni kreatywność, która wraz z pozostałymi formami aktywności muzycznej wspomaga rozwój ogólny i muzyczny dziecka. Przedmiotem, rozważań autorek artykułu są również kwestie weryfikacji skuteczności koncepcji, która nastąpiła w wyniku przeprowadzenia badań empirycznych w szkołach podstawowych. Zebrany materiał badawczy dostarczył wielu spostrzeżeń istotnych dla zmodyfikowania procesu dydaktyczno-wychowawczego. W podsumowaniu zostaną ujęte również problemy, jakie występują w realizacji koncepcji we współczesnej szkole.
\end{abstract}

Słowa kluczowe: edukacja muzyczna, kreatywność, Krakowska Koncepcja Wychowania Muzycznego

\section{WPROWADZENIE}

Elementem edukacji muzycznej może być twórczość. Krakowska Koncepcja Wychowania Muzycznego stwarza warunki do tego, żeby odbywała się ona w sposób aktywny. Według Edwarda Nęcki,twórczość to zdolność osoby do produkowania 
wytworów, charakteryzujących się koniunkcją dwóch cech: nowości i wartości. Aby uniknąć nieporozumień związanych z wieloznacznością słowa twórczość, coraz częściej używa się w tym przypadku terminu kreatywność. Kreatywność przejawia się zwykle $\mathrm{w}$ jakiejś formie obserwowalnego zachowania, polegającego na produkcji nowych i wartościowych wytworów" (Nęcka, 2002, s.19). W odniesieniu do twórczości muzycznej dzieci trudno wziąć pod uwagę wartość wytworu, dlatego opowiadamy się za podejściem egalitarnym -każde dziecko jest twórcze, tylko w niejednakowym stopniu.

\section{CEL PRACY}

Celem niniejszego artykułu jest omówienie założeń Krakowskiej Koncepcji Wychowania Muzycznego (KKWM) w świetle obowiązującej podstawy programowej. Ponadto przedstawieni zostaną twórcy i kontynuatorzy idei oraz wyniki badań przeprowadzonych w oparciu o wspomnianą koncepcję metodyczno-programową. Szczególne znaczenie przypisanodziałaniom twórczym w przygotowaniu do percepcji muzyki, które, obok śpiewu, gry na instrumentach i ruchu z muzyką, są formami aktywności muzycznej stosowanymi na lekcjach muzyki we współczesnej szkole ogólnokształcącej.

\section{OPIS STANU WIEDZY}

Krakowska Koncepcja Wychowania Muzycznego powstała w połowie lat 70.ubiegłego stulecia, a twórcą jej była Zofia Burowska - muzyk i pedagog. Wszechstronne wykształcenie, duże doświadczenie pedagogiczne w pracy z dziećmi i młodzieżą oraz studia nad koncepcjami Zoltána Kodálya, Carla Orffa i Emila Jaques-Dalcroze’a sprawiły, że Z. Burowska aktywnie włączyła się w nurt przemian, jakie zachodziły w polskim szkolnictwie w latach 60. i 70. XX wieku (Kurcz 2014, s. 12). W tym miejscu warto wymienić najważniejsze publikacje Z. Burowskiej i jej zespołu: Wspótczesne systemy wychowania muzycznego (1976), Stuchanie i tworzenie muzyki (1980), Psychodydaktyka muzyczna. Zarys problematyki(wspólnie z E. Głowacką, 1998), Krakowska Koncepcja Wychowania Muzycznego w świetle przeprowadzonych badań (1994), Wprowadzenie w kulturę muzyczną(1991), Metody kształcenia stuchu muzycznego dzieci w wieku szkolnym(A. Wilk, 1996); artykuły zamieszczone w czasopismach muzycznych: Metoda względna w kształceniu stuchu, Wychowanie muzyczne na szczeblu nauczania poczatkowego oraz kilka podręczników i przewodników metodycznych, takich jak: So mi la i La ti do. 
Koncepcję współtworzyli pracownicy Akademii Muzycznej w Krakowie: Jerzy Kurcz i Andrzej Wilk. W kolejnych latach do grona współpracowników dołączyli: Barbara Karpała,Bożenna Noworol, Romualda Ławrowska oraz Andrzej Cebulak. Ważną rolę w procesie wdrożeniowym koncepcji odegrali nauczyciele ówczesnego wychowania muzycznego, późniejszego przedmiotu muzyka: Grażyna Smukalska, Anna Grudzień i Janina Bałuszyńska. Badania empiryczne prowadzone przez krakowskich naukowców to głównie badania diagnostyczne i eksperymentalne. Problematyka badawcza na początku istnienia krakowskiej koncepcji w głównej mierze obejmowała dwa ważne problemy edukacyjne:

- umiejętność czytania nut głosem za pomocą metody solmizacji relacyjnej i absolutnej oraz sprawdzenie ich skutecznościna lekcjach muzyki w szkole podstawowej;

- znaczenia twórczości muzycznej dzieci w przygotowaniu do percepcji muzyki (por. Wilk, Waligóra 2015, s. 88-89).

Badania powyższe, obejmujące swym zasięgiem miasto Kraków i południową część kraju, prowadzili: Z. Burowska, J. Kurcz i A. Wilk. Otrzymane wyniki potwierdziły słuszność przyjętych hipotez i dowiodły skuteczności postępowania dydaktycznego. Zastosowane podczas badań środki percepcji i ekspresji muzycznej były jednymi z pierwszych prób wdrożenia elementów systemów wychowania muzycznego Z. Kodálya i C. Orffa w Polsce. Tym samym rozpoczęto poszukiwanie nowej koncepcji programowo-metodycznej, która by umożliwiała nauczycielowi w procesie dydaktyczno-wychowawczym naturalną integrację form - rodzajów aktywności muzycznej i korelację muzyki z innymi dziedzinami edukacji szkolnej (por. Wilk 2004, s. 34).

Cechami charakterystycznymi krakowskiej koncepcji programowo-metodycznej są:

- ścisła systematyzacja materiału nauczania podporządkowana zasadom metody solmizacji relacyjnej;

- spiralny układ treści nauczania-uczenia się;

- wykorzystanie różnorodnych środków ekspresji i percepcji muzycznej, czyli zgodnie z terminologią KKWM: zastosowanie odpowiednich rodzajów aktywności muzycznej, takich jak śpiewanie, gra na instrumentach, ruch przy muzyce, tworzenie muzyki, słuchanie - w połączeniu z czynnościami wychowania muzycznego. W skład czynności wchodziły ćwiczenia z emisji głosu, ćwiczenia dykcyjne, wprowadzenie notacji muzycznej (na początku procesu edukacyjnego za pomocą liniatury, a następnie pięciolinii) oraz przekazywanie podstawowej wiedzy o muzyce;

- wykorzystanie materiału muzycznego odpowiednio dobranego pod względem wartości artystycznych i dydaktycznych;

- wykorzystanie słowa i tekstów literackich w rozwijaniu wyobraźni muzycznej; 
- integracja tworzenia i słuchania muzyki (red. Burowska, Kurcz, Wilk 1994, s. 5).

Słuchanie muzyki, jak podkreśliła Z. Burowska, jest bardzo ważną formą w procesie wychowania muzycznego. Jako czynność mimowolna występuje w trakcie realizacji wszystkich ww. form aktywności, jednak na uwagę zasługuje tu świadoma percepcja muzyki (Burowska 1976, s. 38). Przybliża ona uczniom zróżnicowaną literaturę muzyczną, uczy wrażliwości na cechy tej dziedziny sztuki, pozwala określić aparat wykonawczy, budowę utworu i jego formę muzyczną, zwraca uwage na elementy dzieła muzycznego. Wszystko to pomaga odkryć emocjonalny charakter muzyki. Nie mniej istotne jest przekazywanie wiedzy o kulturze muzycznej zarówno rodzimego kraju, jak i innych narodów. Stosowana w nauce słuchania muzyki metoda problemowo-analityczna przyczynia się do rozwijania umiejętności uczniów do samodzielnego słuchania i analizowania utworu muzycznego. Z kolei w zakresie tworzenia muzyki dziecko już od najmłodszych lat tworzy proste ilustracje dźwiękowe do tekstów i obrazów oraz improwizacje ruchowe do muzyki. W dalszym toku kształcenia muzycznego pojawia się improwizacja głosem i na instrumentach szkolnych (Konkol 2015, s. 16). Tworzenie muzyki jest jedyną formą, która pozwala na głębokie wniknięcie w strukturę utworu muzycznego. Dodatkowo doskonale motywuje uczniów do poznania i doskonalenia zapisu muzycznego własnych kompozycji (por. Burowska 1976, s. 42). Ponadto na uwagę zasługuje rozwój twórczej aktywności dziecka (szerzej: Gloton, Clero 1976) oraz pogłębianie jego doznań estetycznych w kontakcie z dziełami sztuki (por. Konkol 2014). Obok tworzenia również słuchanie muzyki jest formą rozwijającą wrażliwość estetyczną.

Analizują twórczość muzyczną dziecka można wyróżnić następujące jej typy: spontaniczną aktywność twórczą, która nie ma na celu powstania trwałego wytworu; ekspresję własną mogącą uwidaczniać się w odtwarzaniu muzyki oraz „[...] twórczą aktywność przejawiającą się w umiejętności adaptacji reguł do konkretnego przypadku, modyfikacji wzorów według określonych założeń na podstawie posiadanych informacji z zastrzeżeniem, że zarówno proces tworzenia jak i sam wytwór nie musi być przejawem ekspresji własnej” (red. Burowska, Kurcz, Wilk 1994, s. 41). Ten ostatni typ miał zasadnicze znaczenia dla stworzonej przez Z. Burowską koncepcji metodycznej polegającej na integracji dwóch form aktywności: słuchania oraz tworzenia muzyki. Zgodnie z tym typem nakierowany przez nauczyciela proces tworzenia muzyki przez uczniów wykorzystuje wiedzę zdobytą podczas słuchania muzyki. Zależność zachodzi również w procesie słuchania muzyki, gdzie wykorzystana zostaje wiedza osiągnięta poprzez aktywność twórczą jednostki. Zatem, jak podsumowała Burowska: „[...] aktywność twórcza 
służy percepcji muzyki, a percepcja inspiruje tworzenie" (red. Burowska, Kurcz, Wilk 1994, s. 42).

Zdaniem Burowskiej, jednym $\mathrm{z}$ warunków wpływających na efektywność nauczania jest właściwy dobór materiału nauczania. Proponowane do słuchania utwory powinny być wartościowe i nadające się do percepcji przez dzieci (krótkie, posiadające wyraźny rys melodyczny lub czytelną, powtarzającą się figurę metro-rytmiczną; zawierające wyraźnie określony poprzez zmianę barwy czy dynamiki kontrast pomiędzy częściami). Utwory te powinny posiadać łatwy do określenia nastrój, budzić skojarzenia pozamuzyczne, mieć charakter programowy lub charakterystyczną cechę odróżniającą go od innych. Przedstawiane uczniom przykłady literatury muzycznej powinny dostarczyć imjak najwięcej różnych doświadczeń muzycznych w zakresie stylu, gatunków czy aparatu wykonawczego. W omawianej koncepcji wykorzystuje się utwór muzyczny jako źródło inspiracji w tworzeniu muzyki. Proces tworzenia ma przyczynić się do lepszego zrozumienia muzyki przez dziecko i wzbogacić jego sferę emocjonalną (Burowska 1980, s. 9-10). Dlatego też wyprzedzające słuchanie utworu ćwiczenia twórcze mają ukierunkować uwagę dziecka na wybrany element lub zjawisko charakterystyczne dla danego utworu. W przypadku muzyki programowej jej treść emocjonalna (program) ma zostać określona przez uczniów. Obserwowanie środków wyrazu muzycznego należy rozpocząć od dynamiki, ale równie łatwe do percepcji jest też tempo i jego zmiany oraz barwa dźwięku. Natomiast trudniejsze są: melodia, rytm, frazowanie, artykulacja. Percepcja elementów dzieła muzycznego stanowi jeden z warunków rozumienia i przeżywania muzyki. W sposób analogiczny do systematyzacji elementów w słuchaniu powinna być przeprowadzone tworzenie muzyki na zadany temat. Pośród zadań powinny być takie, których temat wiąże się z tytułem utworu programowego przeznaczonego do słuchania. Należy zauważyć, że w zadaniach rytm i wysokość dźwięku mogą być dowolne, natomiast środki wykonawcze wokalne i instrumentalne, ogólny schemat utworu, jego tempo i dynamika mają być wcześniej ustalone. Szczególne znaczenie ma wynikająca z treści budowa utworu (Burowska 1980, s. 44 i dalsze).

Założenia Krakowskiej Koncepcji Wychowania Muzycznego to efekt prac jej twórców nad studiowaniem literatury z zakresu historii wychowania muzycznego, historii muzyki, pedagogiki estetyki i psychologii. Dzięki temu krakowska koncepcja jest propozycją kształcenia wielostronnego. Niezwykle ważnym elementem z punktu widzenia skuteczności kształcenia jest zróżnicowanie celów na każdym etapie nauczania, co wynika z psychofizycznego i emocjonalnego rozwoju uczniów. Dalsze lata przyniosły prace nad wdrożeniem metodycznych rozwiązań.

Wśród wielu badań empirycznych prowadzonych przez współpracowników Z. Burowskiej na szczególną uwagę zasługują dwa z nich: 
1. Badanie recepcji 92 muzycznych audycji radiowych emitowanych przez IV program Polskiego Radia w trzech cyklach: Zatańczymy raz $i d w a$, zaśpiewamy so mi la (39 audycji dla klasy pierwszej), Jak to ładnie brzmi la so do re mi (27 audycji dla klasy drugiej), Zaśpiewajmy - posłuchajmy (26 audycji dla klasy trzeciej);

2. Badanie kompetencji muzyczno-pedagogicznych studentów pedagogiki przedszkolnej i wczesnoszkolnej Akademii Pedagogicznej w Krakowie (obecnie Uniwersytet Pedagogiczny) w latach 1992-1999.

Audycje radiowe emitowane przez IV program Polskiego Radiaswym zasięgiem obejmowały niemal wszystkie województwa kraju, gromadząc dzieci z klas młodszych przed odbiornikami. W czasie 25 audycji muzycznych uczniowie słuchali i wykonywali utwory muzyczne, które stanowiły podstawę do różnego rodzaju ćwiczeń słuchowo-głosowych, twórczych, muzyczno-słuchowych, umiejętności gry na instrumentach szkolnych i poznawania zapisu nutowego. Każda audycja była ważnym ogniwem z nawiązaniem do poprzedniej i zapowiedzią następnej. Rozpoczynała się i kończyła sygnałem muzycznym, dostosowanym pod względem trudności do umiejętności uczniów danej klasy. Audycje były dedykowane uczniom, a dodatkowo stały się środkiem pomocniczym w pracy nie tylko dla nauczycieli o wysokich kwalifikacjach, ale także dla nauczycieli o nieco niższych kompetencjach muzyczno-pedagogicznych (Wilk, Waligóra 2015, s. 93).

Ze względu na tematykę niniejszej publikacji, ograniczymy się do prezentacji kilku rodzajów ćwiczeń twórczych:

- rytmizowanie (tekstów z towarzyszeniem instrumentów perkusyjnych, wierszy, przysłów, imion, wyliczanek w metrum dwu i trójdzielnym);

- improwizacja (opowiadań na fortepianie o zróżnicowanym charakterze, ruchowa do śpiewanek, inscenizacji do wierszy);

- dopasowywanie oprawy i ilustracji muzycznej do bajek, baśni, opowiadań własnych, środków wykonawczych w celu ilustrowania zjawisk akustycznych, tworzenie tytułów do wysłuchanych utworów ilustracyjnych;

- ćwiczenia w operowaniu elementami muzyki, takimi jak dynamika, tempo, kontynuowanie i kończenie nieznanych melodii głosem, elementarne kształtowanie formy AB, ABA za pomocą ruchu, gry i śpiewu, przekształcenie metrum.

Uzyskane w toku badań wyniki zarówno ilościowe jak i jakościowe potwierdziły wysoką przydatność nowej koncepcji programowo-metodycznej w edukacji artystycznej uczniów klas początkowych szkoły podstawowej. Przeprowadzono sześć sprawdzianów osiągnięć muzycznych i otrzymano 79-96\% bezbłędnych odpowiedzi. Zadania dotyczyły umiejętności rozpoznawania utworu o budowie formalnej AB czy ABA, określenia tańca na podstawie jego charakteru i rytmu, 
rozpoznawania brzmienia różnych instrumentów muzycznych na tle zespołów orkiestrowych. Badanie jakościowe dotyczyło umiejętności kojarzenia muzyki z treściami pozamuzycznymi i polegało na nadaniu tytułu nieznanemu utworowi muzycznemu, w tym przypadku było to Źródło Aretuzy Karola Szymanowskiego. Większość uczniów trafnie określiła pozamuzyczny tytuł, na przykład: Źródełko, Szemrzacy strumyk, Ważka nad rzeka, ale pojawiły się też inne propozycje, takie jak: W ciemnej komnacie, Zardzewiałe skrzypce. Otrzymano również 83 opowiadania, 53 streszczenia własnych bajek, baśni, opowiadań, w których sugerowano zastosowanie poznanych utworów jako ilustracji muzycznych. Uczniowie proponowali też wprowadzenie efektów dźwiękonaśladowczych przy użyciu instrumentów szkolnych, użycie określeń słownych adekwatnych do charakteru muzyki lub dostosowanych do treści i wyrazu emocjonalnego opowiadania (Wilk 2004, s. 39-42).

Z kolei przedmiotem badań Jerzego Kurcza było Znaczenie twórczości muzycznej uczniów klas I-III szkoły podstawowej w przygotowaniu do percepcji muzyki. Stanowiły one próbę znalezienia odpowiedzi na następujące pytania: „Czy istnieje możliwość przełamania trudności w procesie uprzystępniania dziecku muzyki artystycznej? Na ile doświadczenia muzyczne zdobywane w procesie tworzenia $\mathrm{w}$ połączeniu $\mathrm{z}$ odpowiednio dobranymi przykładami muzycznymi rozszerzą możliwości percepcyjne dziecka, stając się podstawą do odbioru muzyki różnych epok stylistycznych?” (Kurcz 1994, s. 22).Poszukiwanie odpowiedzi na wyżej wymienione pytania stały się głównym celem podjętej empirycznej weryfikacji propozycji programowo-metodycznej opartej „uczeniu się przez odkrywanie”. Istotą koncepcji było przygotowanie uczniów do słuchania muzyki poprzez własną aktywność twórczą. Problem główny zawierał się w pytaniu: czy i w jakim stopniu i pod jakim względem elementarne tworzenie (operowanie elementami formotwórczymi) na lekcjach wychowania muzycznego wpływa na rozwój zdolności percepcji utworów muzycznych?W uszczegółowionej postaci problem główny obejmował: zagadnienia dotyczące percepcji treści wyrazowych i programowych utworów muzycznych, a więc odnoszące się do sfery emocjonalnej oraz zagadnienia dotyczące wiedzy i umiejętności muzycznych.

Zaprojektowane badania eksperymentalne miały ustalić, czy propozycja programowo-metodyczna przewyższa tradycyjny sposób prowadzenia zajęć i czy będzie miała oddziaływanie na kształtowanie się u uczniów określonych upodobań muzycznych (red. Burowska, Kurcz, Wilk, 1994, s. 22). Weryfikację hipotezy zakładającej, że twórczość muzyczna - ujmowana jako forma aktywności uczniów - jest najskuteczniejszym sposobem prowadzącym do poznania i rozumienia języka muzycznego, potwierdzono w drodze badań empirycznych. Badania te o charakterze naturalnego eksperymentu pedagogicznego z zastosowaniem techniki grup równoległych przeprowadzono w roku szkolnym 1975/1976 w klasach trzecich 
Szkół Podstawowych nr 1 i nr 10 w Krakowie. Łączna liczba objętych badaniami uczniów wynosiła 99, w tym do grupy eksperymentalnej uczęszczało 47 uczniów, a do kontrolnej 52. Czynnikiem eksperymentalnym - zmienną niezależną - było tworzenie muzyki przez dzieci, zachowując pozostałe formy aktywności wychowania muzycznego. W klasie kontrolnej proces dydaktyczny przebiegał zgodnie z obowiązującym programem nauczania, który opierał się głównie na nauczaniu pieśni.

Narzędziami badawczymi zastosowanymi do pomiaru końcowego były: Test Słuchania Muzyki, Test Inteligencji Muzycznej H. Winga (wersja skrócona) oraz Sprawdzian dotyczący upodobań muzycznych.

Otrzymane wyniki badań, których szczegółową prezentację pominiemy, po opracowaniu statystycznym dowiodły, że: uczniowie z klas eksperymentalnych wykazali zdecydowanie lepszą orientację w zakresie zagadnień muzycznych oraz prezentowali bardziej wyrównany poziom w zakresie umiejętności i wiedzy muzycznej. Ponadto elementarne tworzenie muzyki przez uczniów w klasach eksperymentalnych dało możliwość głębszego wniknięcia w istotę muzyki w porównaniu z klasami kontrolnymi, tym samym przygotowania do percepcji utworów muzycznych. $\mathrm{Na}$ podstawie uzyskanych wyników można wysnuć wniosek, że uczniowie z grupy eksperymentalnej w sposób bardziej świadomy stosowali właściwe określenia odnoszące się do strony wyrazowej muzyki w porównaniu z uczniami grupy kontrolnej. W utworach o ilustracyjnym charakterze, do których dobierano tytuły, a także w przypadku badania upodobań i preferencji muzycznych nie zauważono wyraźnych różnic pomiędzy grupami eksperymentalnymi i kontrolnymi. W konkluzji J. Kurcz podkreślił: „Istotne znaczenie dla przygotowania uczniów do percepcji muzyki ma proces dydaktyczny polegający na integracji dwu form aktywności muzycznej dziecka, to jest tworzenia i słuchania muzyki”(Kurcz 1994 s. 23-24).

Pozytywny wynik badań J. Kurcza (Kurcz 1978) stał się podstawą do dalszych badań i poszukiwania odpowiedzi na pytanie o to: „[...] czy proces dydaktyczny polegający na integracji tworzenia i słuchania muzyki może stymulować rozwój zdolności percepcji muzyki oraz czy zachodzi współzależność pomiędzy podstawowymi zdolnościami muzycznymi a zdolnościami odbiorczymi?” (Burowska 1994, s. 42). Przyjęto założenie, że własna muzyczna aktywność twórcza może przyczynić się do przyśpieszenia rozwoju zdolności percepcji muzyki, a ponadto, że istnieje współzależność pomiędzy podstawowymi zdolnościami muzycznymi a zdolnością percepcji. Weryfikację hipotezy przeprowadzono w oparciu o naturalny eksperyment pedagogiczny, a wyniki końcowe uzyskano na podstawie analizy porównawczej osiągnięć grupy eksperymentalnej i grupy kontrolnej oraz wyników testu A. Bentleya i wyników testu słuchania muzyki (szerzej: Burowska 1994, s. 42 i dalsze).Wyniki badań przeprowadzonych wśród uczniów jednej ze szkół podstawowych w Krakowie w 1983 roku dowiodły, iż działalność dydak- 
tyczna skupiona na integracji tworzenia i słuchania muzyki ma istotne znaczenie w rozwijaniu zdolności percepcji muzyki i może przyspieszyć rozwój tej zdolności. Działalność przyczynia się również do rozwoju pozytywnych motywacji i postaw wobec słuchanej muzyki. Nie stwierdzono natomiast współzależności pomiędzy podstawowymi zdolnościami muzycznymi mierzonymi testem Bentleya a zdolnościami percepcji mierzonymi testem słuchania muzyki. Sformułowano postulat przeprowadzenia dalszych pogłębionych badań, które miałyby znaczenie dla dydaktyki słuchania muzyki (Burowska 1994, s. 47).

Upowszechnianie krakowskiej koncepcji można dostrzec w działalności pedagogiczno-pedeutologicznej w kształceniu studentów Akademii Muzycznej w Krakowie oraz studentów kierunku pedagogika wczesnoszkolna i przedszkolna Uniwersytetu Pedagogicznego im. KEN w Krakowie oraz Państwowej Wyższej Szkoły Zawodowej w Nowym Sączu (Kalarus 2009). W oparciu o założenia programowo-metodyczne Grażyna Enzinger i Bożena Raszke opracowały model kształcenia muzycznego, zwany „modelem nowosądeckim”.Wiele badań empirycznych do prac magisterskich i licencjackich w oparciu o osiągnięcia krakowskiej koncepcji jest prowadzonych w Katedrze Badań Muzyczno-Edukacyjnych. Między innymi badania dotyczące zastosowania ćwiczeń twórczych w zakresie elementów formotwórczych w przygotowaniu do słuchania muzykina grupie przedszkolnej 4-6-latków w Przedszkolu Montessori przeprowadziła studentka studiów licencjackich Akademii Muzycznej w Krakowie Justyna Woszczak pod opieką naukową Anny Kalarus, uzyskując cenne i interesujące wyniki.

Uwzględniając główny cel edukacji muzycznej w szkole powszechnej, czyli przygotowanie uczniów do aktywnego uczestnictwa w życiu muzycznym, twórcy krakowskiej koncepcji przygotowali dwie książki przeznaczone dla nauczycieli muzyki. Tytuły książek wynikają z postępowania dydaktycznego i z zastosowanej relacyjnej metody kształcenia słuchu. Pierwsza z nich, So mi la, (Burowska i in. 1998) zawiera materiał nauczania dla klas 1-3, druga, $L a, t i$, do, (Burowska i in. 1993) stanowi kontynuację pierwszego podręcznikai jest przeznaczona dla nauczycieli dla klas $4-8$.

We Wstępie autorzy informują czytelnika, że: „[...] dobór materiału muzycznego został podporządkowany określonej koncepcji metodycznej. Jej istotę stanowi zasada:

- systematyzacji materiału nauczania, wynikająca z zastosowania metody relatywnej (relacyjnej) w nauce czytania nut głosem,

- stopniowego wprowadzania zasad „krok po kroku” w powiązaniu z materiałem poznanym i utrwalonym,

- integracji form aktywności muzycznej: śpiewania, grania, tworzenia, słuchania muzyki, 
- korelacji nauczania muzyki z innymi przedmiotami szkolnymi" (Burowska i in. 1993, s. 5).

W podręczniku So mi la, który został podzielony na XII rozdziałów, już w rozdziale II pojawia się tworzenie muzyki poprzez recytację tekstów różnymi sposobami, na przykład:

- wykonanie ze zróżnicowaniem dynamicznym, barwowym i wyrazowym (powtarzanie tekstu smutno, wesoło, groźnie, ze złością, tajemniczo, ospale, ze zdenerwowaniem),

- wykonywanie rytmu bez tekstu na sylabach ze zróżnicowaniem dynamiki i tempa,

- wykonanie rytmu na instrumentachze zróżnicowaniem dynamiki i tempa,

- układanie tekstów z użyciem własnych i nazw, dowolnych sylab do podanych rytmów,

- dobieranie przez uczniów dwóch różnych gestów dla dwóch dotychczas poznanych wartości rytmicznych (ćwierćnuty i ósemki).

W końcowej części rozdziału III ćwiczenia rozwijające kreatywność dotyczą słuchu wysokościowego, a są nimi:

- układanie akompaniamentu ostinatowego do poznanych piosenek,

- dobieranie dźwięku towarzyszącego (burdonu) wykonywanego przez dzieci,

- układanie akompaniamentu ilustracyjnego do poznanej śpiewanki

- tworzenie ilustracji muzycznej do wiersza Żuk, której pojawiają się elementy improwizacji wokalnej „żuka” i „biedronki”.

Wyżej wymienione przykłady ćwiczeń są stałym elementem podręcznika, a w kolejnych rozdziałach ich stopień trudności wzrasta.

Podobną zasadę przyjęto w podręczniku La, ti, do dla klas 4-8. Podręcznik ten podzielony jest na IX rozdziałów, każdy z nich zbudowany jest następująco: Echo, Muzykowanie, Zapis, Tworzenie, Słuchanie muzyki, Ćwiczenia sprawdzające. Tworzenie muzyki polega na:

- rytmizowaniu mowy - w celu ułatwienia zrealizowania przez uczniów zadania, autorzy zamieścili przykładowe rozwiązania;

- układaniu perkusyjnego wstępu i zakończenia oraz akompaniamentu do zrytmizowanego tekstu;

- układaniu melodii do zrytmizowanego tekstu;

- dobieraniu rytmów (spośród podanych przykładów) do rytmu wiersza;

- wydłużaniu melodii przez powtórzenie zakończenia lub stworzenie własnego, nowego zakończenia, zakończenie melodii, kontynuowanie melodii;

- uzupełnianiu melodii.

Należy zaznaczyć, że w wyżej wymienionych podręcznikach nie ma podziału na poszczególne klasy. W zależności od poziomu uzdolnień uczniów i ich wcześ- 
niejszego przygotowania, nauczyciel ma możliwość wyboru doboru form i treści tak, aby zapewnić uczniowi holistyczny rozwój.

\section{PODSUMOWANIE}

W ocenie autorek omówiona koncepcja integracji słuchania i tworzenia muzyki jest niezwykle cenną i powinna znaleźć swoje miejsce na lekcjach muzyki we współczesnej szkole. Obecnie obowiązująca podstawa programowa kształcenia ogólnego dla szkoły podstawowej (Rozporządzenie MEN 2017) zakłada na I etapie edukacyjnym - edukacja wczesnoszkolna realizowana w formie kształcenia zintegrowanego (klasy I-III) - szereg osiągnięć w zakresie słuchania muzyki, ekspresji muzycznej (śpiew, improwizacja ruchowa, rytmika i taniec, gra na instrumentach muzycznych, znajomość form zapisu dźwięku). Na II etapie edukacyjnym (klasy IV-VIII) zakres przedmiotu muzyka obejmuje: indywidualną i zespołową ekspresję muzyczną (w zakresie śpiewu, gry na instrumentach, ruchu przy muzyce, słuchania i percepcji muzyki); język i funkcje muzyki, myślenie muzyczne, kreację i twórcze działania oraz wiedzę o kulturze muzycznej, narodowym i światowym dziedzictwie kulturowym. W dokumencie podkreślono, iż podczas organizowania procesu dydaktyczno-wychowawczego należy pamiętać, że działania praktyczne muszą dominować nad zagadnieniami teoretycznymi, a wszelkie wiadomości z zakresu teorii i historii muzyki powinny stanowić ich uzupełnienie.

W zakończeniu założeń dla przedmiotu muzyka czytamy: „Należy zachować szczególną dbałość o jakość edukacji muzycznej warunkowaną wielością i różnorodnością doświadczeń w zakresie śpiewu, gry na instrumentach, tworzenia i improwizowania muzyki, kreatywności muzycznej, słuchania i percepcji muzyki oraz ruchu z muzyką i tańca. Wszelka aktywność muzyczna prowadzi do zdobycia niezbędnych wiadomości teoretycznych przez uczniów. Rodzaj aktywności muzycznej powinien być elastycznie dostosowany do indywidualnych predyspozycji każdego ucznia. Realizacja zajęć winna umożliwiać każdemu uczniowi rozwijanie kreatywności oraz kompetencji społecznych, takich jak: współdziałanie, współodpowiedzialność, umiejętność prezentacji osiągnięć indywidualnych i zespołowych, pełnienie różnorodnych funkcji w grupie, tolerancję dla gustów i upodobań oraz tradycji kulturowych odmiennych od własnych (Rozporządzenie MEN, 2017, s. 86-87).

Realizacja powyższych założeń, zdaniem autorek, powinna odbywać się z uwzględnieniem twórczej aktywności ucznia. Koncepcja metodyczno-programowa integracji tworzenia i słuchania muzyki Zofii Burowskiej wpisuje się w ten nurt.

Autorki składają serdeczne podziękowania prof. dr. hab. Jerzemu Kurczowi oraz dr. Andrzejowi Wilkowi za udostępnienie niepublikowanych materiałów. 


\section{LITERATURA}

Burowska Z., 1976, Współczesne systemy wychowania muzycznego. Warszawa, WSiP. BurowskaZ., 1980, Stuchanie i tworzenie muzykiw szkole. Warszawa, WSiP,.

Burowska Z., 1991, Wprowadzenie w kulture muzyczną, Warszawa.

Burowska Z., Głowacka E., 1998, Psychodydaktyka muzyczna. Zarys problematyki. Kraków Akademia Muzyczna w Krakowie.

Burowska Z., Karpała B., Noworol B., Wilk A., 1989, So mi la. Ćwiczenia muzyczne w klasach I-III. Książka pomocnicza dla nauczyciela, Warszawa, WSiP.

Burowska Z., Karpała B., Kurcz J., Wilk A., 1993, La, ti, do.Ćwiczenia muzyczne w klasach I-III. Książka pomocnicza dla nauczyciela. Warszawa, WSiP.

Burowska Z., Kurcz J. Wilk A. red., 1994, Krakowska Koncepcja Wychowania Muzycznego w świetle przeprowadzonych badań. KrakówAkademia Muzyczna w Krakowie. Gloton R., Clero C., 1976, Twórcza aktywność dziecka, tłum. I. Wojnar. Warszawa, WSiP. Kalarus A., 2009, W poszukiwaniu skutecznych koncepcji kształcenia muzycznego dzieci. W: Z. Zacłon (red.), Refleksje nad jakością pracy szkoły. Nowy Sącz, PWSZ.

Konkol G.K., 2014, Znaczenie muzyki w wychowaniu estetycznym dzieci i młodzieży. Polska koncepcja wychowania muzycznego. OSW Szkice Humanistyczne, t. 14, nr 1-2.

Konkol GK., 2015,Stuchanie i tworzenie muzyki w szkole. „Wychowanie Muzyczne”, 2. Kurcz J., 1994, Znaczenie twórczości muzycznej uczniów klas I-III szkoły podstawowej w przygotowaniu do percepcji muzyki. W: Burowska Z., Kurcz J. Wilk A. (red.), Krakowska koncepcja wychowania muzycznego. Akademia Muzyczna w Krakowie. Kurcz J., 2014, Zofia Burowska i Jej pedagogiczne credo. „Wychowanie Muzyczne”, 5. Kurcz J., 1978, Znaczenie twórczości muzycznej w przygotowaniu do percepcji. Niepublikowana praca doktorska, Kraków, Uniwersytet Jagielloński.

Nęcka E., 2002, Psychologia twórczości. Gdańsk, GWP.

Wilk A., Waligóra M., 2015, Krakowska Koncepcja Wychowania Muzycznego w teorii $i$ w praktyce pedagogicznej. W: Sternal M. red., Do kultury muzycznej droga najwłaściwsza. Zagadnienia twórczości, wykonawstwa i edukacji muzycznej. Kraków, Akademia Muzyczna w Krakowie.

Wilk A., 1996, Metody kształcenia muzycznego dzieci w wieku szkolnym, wyd. II. Kraków, Wydawnictwo Naukowe WSP.

Wilk A., 2004, Problemat kompetencji muzyczno-pedagogicznych studentów pedagogiki wczesnoszkolnej i nauczycieli klas początkowych szkoły podstawowej w świetle przeprowadzonych badań w latach 1992-1999. Kraków, Wydawnictwo Naukowe Akademii Pedagogicznej.

Rozporządzenie Ministra Edukacji Narodowej z dnia 14 lutego 2017 r. w sprawie podstawy programowej wychowania przedszkolnego oraz podstawy pro- 
gramowej kształcenia ogólnego dla szkoły podstawowej, w tym dla uczniów z niepełnosprawnością intelektualną w stopniu umiarkowanym lub znacznym, kształcenia ogólnego dla branżowej szkoły I stopnia, kształcenia ogólnego dla szkoły specjalnej przysposabiającej do pracy oraz kształcenia ogólnego dla szkoły policealnej, opublikowano: http://dziennikustaw.gov.pl/du/2017/356/1 [dostęp: 14.09.2018].

THE PLACE FOR CREATIVITY IN THE CRACOW CONCEPT OF MUSICAL EDUCATION

\begin{abstract}
This article will present the achievements of the Cracow academics involved in the search for effective methods of teaching music in general education schools. The Cracow center was established on the initiative of Professor Zofia Burowska in the mid-seventies of the 20th century. The researchers from the Higher Music Education Institutionand Pedagogical University at that time became members of the staff. The programme and methodological assumptions which were adopted are based on relational solmization method, derived from the English Tonic-Solfa method by John Curwen and the concept by Zoltán Kodály. An important role in the Cracow Concept of Musical Education is creativity, which, along with other forms of musical activity, supports the general and musical development of a child. The subject of the authors' deliberating is also the issues concerning verification of the effectiveness of the concept, which occurred as a result of empirical research in primary schools. The collected research material provided many important insights relevant to the modification of the educational process. In summary, the problems which appear during the implementation of the concept in contemporary school will also be presented.
\end{abstract}

Keywords: music education, creativity, the Cracow Concept of Musical Education 